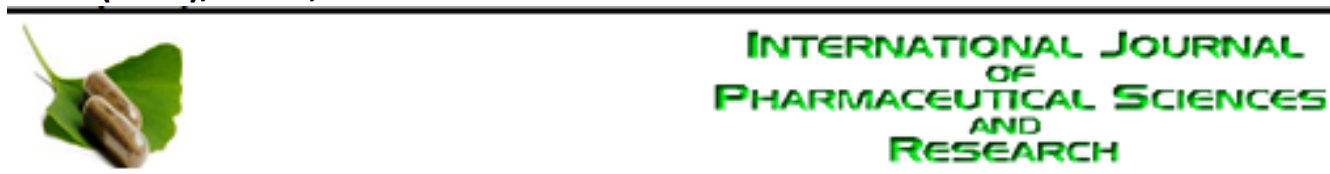

Received on 15 July, 2012; received in revised form 03 September, 2012; accepted 29 October, 2012

\title{
FORMULATION AND EVALUATION OF FLOATING TABLETS OF OFLOXACIN
}

Saigeethika S. ${ }^{*}$, Gautam Singhvi ${ }^{2}$ and Ramanjaneyulu ${ }^{1}$

Formulation Development Unit, Department of Pharmacy, V.I.P.E.R. ${ }^{1}$, Medak, Andhra Pradesh, India Formulation Development Laboratory, Department of Pharmacy, B.I.T.S. ${ }^{2}$, Pilani, Rajasthan, India

\section{ABSTRACT}

Keywords:

Ofloxacin,

Effervescent,

Floating Tablet,

Release Mechanism

Correspondence to Author:

\section{S. saigeethika}

Vishnu Institute of Pharmaceutical Education \& Research, Narsapur, Medak502313, Andhra Pradesh, India

E-mail: geethikachaudhary@gmail.com

\begin{tabular}{|c|c|}
\hline \multirow{3}{*}{ 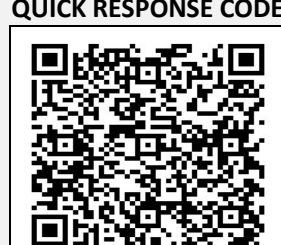 } & \\
\hline & $\begin{array}{c}\text { IJPSR: } \\
\text { ICV (2011)- } 5.07\end{array}$ \\
\hline & $\begin{array}{c}\text { Website: } \\
\text { www.ijpsr.com }\end{array}$ \\
\hline
\end{tabular}

Ofloxacin is a synthetic chemotherapeutic antibiotic of the fluoroquinolone drug class considered to be a second-generation fluoroquinolone. Gastric emptying of dosage forms is an extremely variable process and ability to prolong and control the emptying time is a valuable asset for dosage forms, which reside in the stomach for a longer period of time than conventional dosage forms. Several difficulties are faced in designing controlled release systems for better absorption and enhanced bioavailability. To overcome the problem of conventional dosageforms ofloxacin effervescent floating tablets were developed in six different formulations (F1 to $F 6$ ) by employing different grades of polymers and effervescent agent sodium bicarbonate. The formulations were evaluated for various physical parameters, buoyancy studies, dissolution parameters and drug release mechanisms. F6 formulation showed good physical parameters and gave slow and maximum drug release of ofloxacin spread over 24 hours and showed maximum similarity with marketed product in dissolution profile. Different kinetic models were applied to drug release data in order to evaluate release mechanisms and kinetics.
INTRODUCTION: Ofloxacin is a new fluoroquinolone derivative with a broad spectrum of activity against a wide variety of bacteria.

Ofloxacin is a synthetic chemotherapeutic antibiotic of the fluoro-quinolone drug class considered to be a second-generation fluoroquinolone. Ofloxacin can be used for the treatment of acute exacerbations of chronic bronchitis, community-acquired pneumonia, skin and skin structure infections (uncomplicated), urethral and cervical gonorrhea (acute, uncomplicated), urethritis and cervicitis (nongonococcal), mixed infections of the urethra and cervix, pelvic inflammatory disease (acute), cystitis (uncomplicated), urinary tract infections (complicated), prostatitis.
The bioavailability of ofloxacin in the tablet form is approximately $98 \%$ following oral administration reaching maximum serum concentrations within one to two hours. Between $65 \%$ and $80 \%$ of an administered oral dose of ofloxacin is excreted unchanged via the kidneys within 48 hours of dosing. Therefore, elimination is mainly by renal excretion. Plasma elimination half-life is approximately 4 to 5 hours in patients. Gastric emptying of dosage forms is an extremely variable process and ability to prolong and control the emptying time is a valuable asset for dosage forms, which reside in the stomach for a longer period of time than conventional dosage forms, it is widely acknowledged that the extent of gastrointestinal tract drug absorption is related to contact time with the small intestinal mucosa ${ }^{1}$. 
Several drug delivery systems with prolonged gastric retention time have been investigated ${ }^{2-4}$. The controlled gastric retention of solid dosage forms may be achieved by the mechanisms of mucoadhesion ${ }^{5,6}$, flotation ${ }^{7}$, sedimentation ${ }^{8,9}$, expansion ${ }^{10,11}$, modified shape systems 12,13 , or by the simultaneous administration of pharmacological agents 14,15 . The floating system in particular has been extensively researched, mainly because the floating system does not adversely affect the motility of the GI tract. The floating sustained release dosage forms present most of the characteristics of hydrophilic matrices and are known as 'hydrodynamically balanced systems' ('HBS').

Since, they are able to maintain their low apparent density, while the polymer hydrates and builds a gelled barrier at the outer surface. The drug is released progressively from the swollen matrix, as in the case of conventional hydrophilic matrices. These forms are expected to remain buoyant (3-4 hours) on the gastric contents without affecting the intrinsic rate of emptying because their bulk density is lower than that of the gastric contents Small-size tablets leave the stomach during the digestive phase while the large-size tablets are emptied during the housekeeping waves ${ }^{16}$. Many results have demonstrated the validity of the concept of buoyancy in terms of prolonged GRT of the floating forms, improved bioavailability of drugs and improved clinical situations.

\section{MATERIALS AND METHODS:}

Materials: Ofloxacin received as a gift sample from IPCA pharmaceutical limited, Mumbai. Hydroxy propyl methyl cellulose (HPMC) 100K (Yarrow chemicals, Mumbai), sodium bi carbonate, polyvinylpyrrolidine, talc and magnesium stearate (S.d fine chemicals, Mumbai) were obtained and used as received. Zanocin commercial product of ofloxacin was purchased from local market.

\section{Methods:}

Preparation of Ofloxacin floating tablets: Ofloxacin tablets were prepared using wet granulation technique. The composition of different formulations of ofloxacin floating tablets is shown in table 1. All the intragranular ingredients except PVP were passed through sieve no. 40\#. After sieving, all the ingredients were weighed accurately and mixed thoroughly following geometric method. Granulation was done with a solution of PVP K-30 in sufficient iso propyl alcohol. The granules passed through $8 \#$ were dried in conventional hot air oven at $45^{\circ} \mathrm{c}$.Drying of granules was stopped when samples reached a loss on drying (LOD) value less than 2\%.the granules were sized through sieve 20\# and lubricated with magnesium stearate and talc.

\section{TABLE 1: COMPOSITION OF FLOATING TABLETS OF OFLOXACIN}

\begin{tabular}{|c|c|c|c|c|c|c|c|}
\hline \multirow{2}{*}{ S. No. } & \multirow{2}{*}{ Composition } & \multicolumn{6}{|c|}{ Quantity } \\
\hline & & F1 & $\mathbf{F 2}$ & F3 & F4 & F5 & F6 \\
\hline 1 & Micro crystalline cellulose & $200 \mathrm{mg}$ & $200 \mathrm{mg}$ & $200 \mathrm{mg}$ & $200 \mathrm{mg}$ & $200 \mathrm{mg}$ & $200 \mathrm{mg}$ \\
\hline 2 & Hydroxy propyl methyl cellulose(100K) & 200 mg & $175 \mathrm{mg}$ & $150 \mathrm{mg}$ & $150 \mathrm{mg}$ & 125 mg & $135 \mathrm{mg}$ \\
\hline 3 & Poly vinyl pyrollidine & $40 \mathrm{mg}$ & $40 \mathrm{mg}$ & $40 \mathrm{mg}$ & $40 \mathrm{mg}$ & $40 \mathrm{mg}$ & $80 \mathrm{mg}$ \\
\hline 4 & Sodium bi carbonate & $80 \mathrm{mg}$ & $100 \mathrm{mg}$ & $120 \mathrm{mg}$ & $100 \mathrm{mg}$ & $100 \mathrm{mg}$ & $100 \mathrm{mg}$ \\
\hline 5 & Magnesium stearate & $10.4 \mathrm{mg}$ & $10.3 \mathrm{mg}$ & $10.2 \mathrm{mg}$ & $9.8 \mathrm{mg}$ & $9.3 \mathrm{mg}$ & $10.3 \mathrm{mg}$ \\
\hline 6 & talc & $10.4 \mathrm{mg}$ & $10.3 \mathrm{mg}$ & $10.2 \mathrm{mg}$ & $9.8 \mathrm{mg}$ & $9.3 \mathrm{mg}$ & $10.3 \mathrm{mg}$ \\
\hline
\end{tabular}

The above blend was then compressed using $10 \mathrm{~mm}$ punch under CADMAK tablet punching machine at $4 \mathrm{~kg} / \mathrm{cm}^{2}$ force.

\section{Evaluation of ofloxacin floating tablets:}

1. Weight variation, Hardness, Friability and Content uniformity: Twenty tablets were selected randomly from each batch and weighed individually to check for weight variation. Hardness of the tablets was tested using a Monsanto hardness tester. Friability of tablets was determined in Roche friabilator.

Ofloxacin content in the tablets was estimated by using UV spectrophotometer at $\lambda_{\max } 294 \mathrm{~nm}$ in phosphate buffer $(\mathrm{pH}$ 1.2). The results of characterization are shown in table 2. 
2. In Vitro Buoyancy Studies: The in vitro buoyancy was determined by floating lag time. The tablets were placed in a $100 \mathrm{ml}$ beaker containing $\mathrm{pH} 1.2$ buffers. The time required for the tablet to rise to the surface and float was determined as floating lag time. This test was performed on 3 tablets from each batch.

3. In-Vitro Dissolution Studies: The release rate of ofloxacin from floating tablets was determined using dissolution testing Apparatus USP II (paddle method). The dissolution test was performed using $900 \mathrm{~mL}$ of $\mathrm{pH} 1.2$ buffer, at $37 \pm 0.5^{\circ} \mathrm{C}$ and $50 \mathrm{rpm}$. A sample of $10 \mathrm{ml}$ was withdrawn from the dissolution apparatus at regular time intervals up to $24 \mathrm{hrs}$. These were filtered and diluted to a suitable concentration with pH 1.2 buffer. The samples were replaced with the same volume of fresh dissolution medium in basket. Absorbance of these solutions was measured at 294 $\mathrm{nm}$ using a UV/VIS spectrophotometer (JASCO). Cumulative percentage drug release was calculated using an equation obtained from a standard curve. $y$ $=0.094 x+0.017$.

4. Analysis of Release Mechanism: In order to examine the release mechanism of Ofloxacin from the prepared floating tablets of the optimized formulation (F6), the results of the dissolution study was examined in accordance to the kinetic models. The regression coefficient $R^{2}$ value nearer to 1 indicates the model fitting of the release mechanism. The results are shown in Table 3 and Figure 2 to 5 .

5. Comparison with Marketed Product: The formulation (F6) In-vitro dissolution profiles were compared with marketed product Zanocin (Ofloxacin). The values of comparative in-vitro dissolution study of optimized formulation (F6) and marketed product were recorded in figure 6.
RESULTS AND DISCUSSION: The floating tablets of ofloxacin were formulated in six different batches F1 toF6. All formulations were prepared by effervescent approach. Sodium bicarbonate was added as a gasgenerating agent. Sodium bicarbonate induced carbon dioxide generation in presence of dissolution medium (1.2 pH buffer). It was observed that the gas generated is trapped and protected with gel, formed by hydration of polymer thus decreasing density of tablet below 1 and tablet becomes buoyant. The tablet swelled radially and axially during in vitro buoyancy studies. The prepared tablets of all the formulations were evaluated for physical characters like tablet hardness, friability, weight variation, buoyancy lag time, total floating time, assay and In-vitro drug release. The results were shown in table 2 .

The weight variation was within range of $\pm 5 \%$ complying with pharmaceutical specifications. The hardness for formulations was found to be between $4.20-4.25 \mathrm{~kg} / \mathrm{cm}^{2}$ indicating satisfactory mechanical strength. The friability was below $1 \%$ for formulations $1,2,4,5 \& 6$ but it exceeds $1 \%$ for formulation 3, which is an indication of less mechanical resistance for formulation 3, may be due to more amount of gas generating agent.

The content varied between $197.74 \mathrm{mg}-199.01 \mathrm{mg}$ in different formulations with coefficient of variation less than $2 \%$ indicating content uniformity in prepared batches. Floating lag time for F 1, F2, F3, F4, F5 \& F6 was $75 \mathrm{sec}, 45 \mathrm{sec}, 15 \mathrm{sec}, 37 \mathrm{sec}, 32 \mathrm{sec}$ and $43 \mathrm{sec}$ respectively. Total floating time for F1, F2, F4, F5 \& F6 was $24 \mathrm{hr}$, but it was $6 \mathrm{hr}$ for F3 (as it disintegrated after $6 \mathrm{hrs}$ ). Increased amount of sodium bicarbonate was found to decrease floating lag time.

TABLE 2: PHYSICAL CHARACTERIZATION OF DIFFERENT FORMULATIONS

\begin{tabular}{|c|c|c|c|c|c|c|}
\hline Code & $\begin{array}{l}\text { Uniformity of } \\
\text { weight (mg) }\end{array}$ & $\begin{array}{c}\text { Hardness } \\
\left(\mathrm{kg} / \mathrm{cm}^{2}\right)\end{array}$ & Friability (\%) & $\begin{array}{l}\text { Drug content } \\
\text { (mg) }\end{array}$ & $\begin{array}{c}\text { Floating lag } \\
\text { time (sec) }\end{array}$ & $\begin{array}{c}\text { Total floating time } \\
\text { (hr) }\end{array}$ \\
\hline $\mathrm{F} 1$ & 543.4 & 4.25 & 0.57 & 198.26 & 75 & 24 \\
\hline $\mathrm{F} 2$ & 533.9 & 4.20 & 0.54 & 197.92 & 45 & 24 \\
\hline F3 & 529.9 & 4.25 & 1.25 & 198.61 & 15 & 6 \\
\hline $\mathrm{F} 4$ & 511.2 & 4.23 & 0.46 & 197.74 & 43 & 24 \\
\hline F5 & 482.9 & 4.27 & 0.62 & 199.01 & 37 & 24 \\
\hline F6 & 534.7 & 4.25 & 0.51 & 198.87 & 52 & 24 \\
\hline
\end{tabular}


It is evident from the in vitro dissolution data that increase in sodium bicarbonate increased the release rate but reduced the floating lag time, probably due to excess of carbon dioxide, disturbing monolithic tablet and as the amount of polymer decreasing the amount of drug release increasing. We can attribute release rate change to amount of polymer change and decrease in lag time to change in amount of sodium bicarbonate. The drug release from floating tablet was found to be $62 \%$ for formulation $1,84 \%$ for formulation 2, $92.8 \%$ for formulation 4 and $97.9 \%$ for formulation 6 at the end of $24 \mathrm{hr}$.

TABLE 3: KINETIC RELEASE DATA OF DIFFERENT MODEL FOR OPTIMIZED FORMULATION (F6) AND MARKETED FORMULATION (MF)

\begin{tabular}{|c|c|c|c|c|c|c|c|c|c|}
\hline \multicolumn{2}{|c|}{$\begin{array}{c}\text { Zero Order } \\
\left(\mathbf{R}^{2}\right)\end{array}$} & \multicolumn{2}{|c|}{$\begin{array}{c}\text { First order } \\
\left(\mathbf{R}^{2}\right)\end{array}$} & \multicolumn{2}{|c|}{$\begin{array}{l}\text { Higuchi } \\
\left(\mathbf{R}^{2}\right)\end{array}$} & \multicolumn{2}{|c|}{$\begin{array}{c}\text { Korsmeyer-Peppas } \\
\left(\mathbf{R}^{2}\right)\end{array}$} & \multicolumn{2}{|c|}{$\begin{array}{c}\text { Korsemeyer-Peppas mode } \\
\text { (n value) }\end{array}$} \\
\hline F6 & $\mathrm{MF}$ & F6 & MF & F6 & MF & F6 & MF & F6 & $\mathrm{MF}$ \\
\hline 0.892 & 0.936 & 0.976 & 0.975 & 0.974 & 0.982 & 0.977 & 0.978 & 0.617 & 0.504 \\
\hline
\end{tabular}

For Marketed product and optimized formulation closer $\mathrm{R}^{2}$ values were obtained in all models (i.e. Zero order, First order, Higuchi model and Korsemeyerpeppas model) whereas marketed formulation fitted well in higuchi model compared to optimized formulation. The value of exponent ' $n$ ' obtained is more than 0.5 in marketed formulation as well as in optimized formulation, hence as per $\mathrm{n}$ value of Korsmeyer \& Peppas can be predicted that drug release mechanism follows non-Fickian law of diffusion. Slope values and $\mathrm{R}^{2}$ values of different kinetic models of marketed formulation and optimized formulation were mentioned in table 3 :

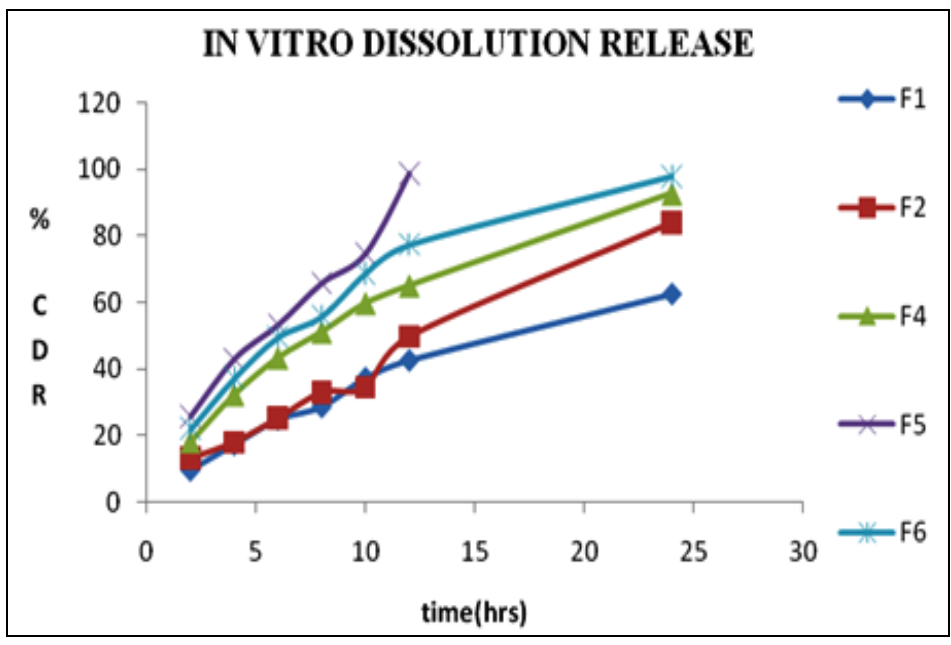

FIGURE 1: IN-VITRO DISSOLUTION PROFILE OF FORMULATIONS F 1 TO F 6 (\% CDR = \% cumulative drug release)
Formulation 5 showed $98.9 \%$ drug release at the end of 18 hrs itself, may be due to less amount of polymer whereas formulation 3 was disintegrated after $6 \mathrm{hrs}$ may be due to increased porosity cause of decrease in polymer amount and increase in gas generating agent. This batch friability was also found out of IP specification. Maximum drug release of Ofloxacin spread over $24 \mathrm{hr}$ was found in F6, Thus F6 formulation was said to be optimized formulation. The data obtained from in vitro dissolution studies of optimized formulation 6 and marketed formulation (MF) were fitted in different models viz. Zero order, First order, Higuchi model and Peppas model (table 3).

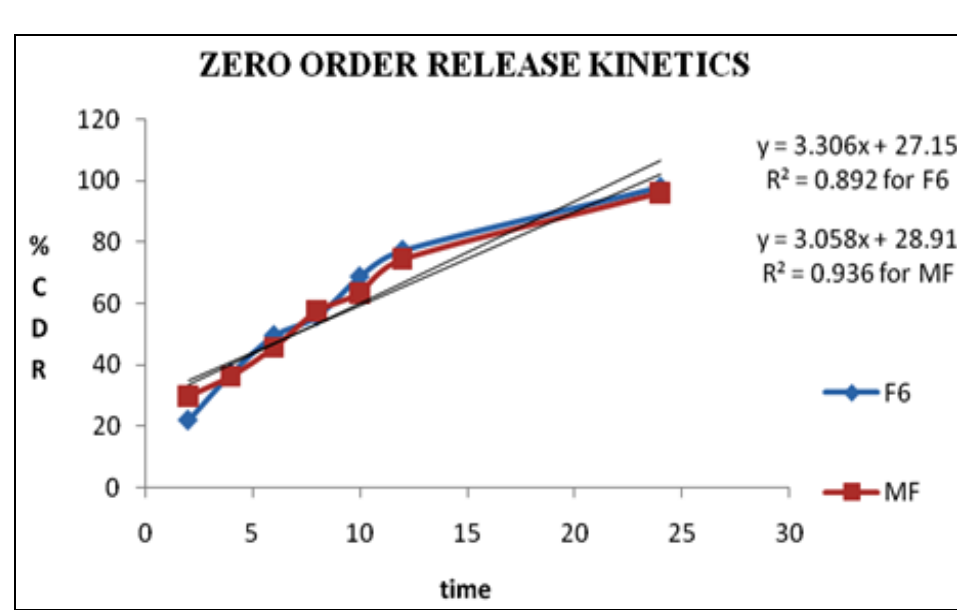

FIGURE 2: PLOT OF CUMULATIVE PERCENTAGE DRUG RELEASED VS. TIME OF OPTIMIZED FORMULATION AND MARKETED FORMULATION

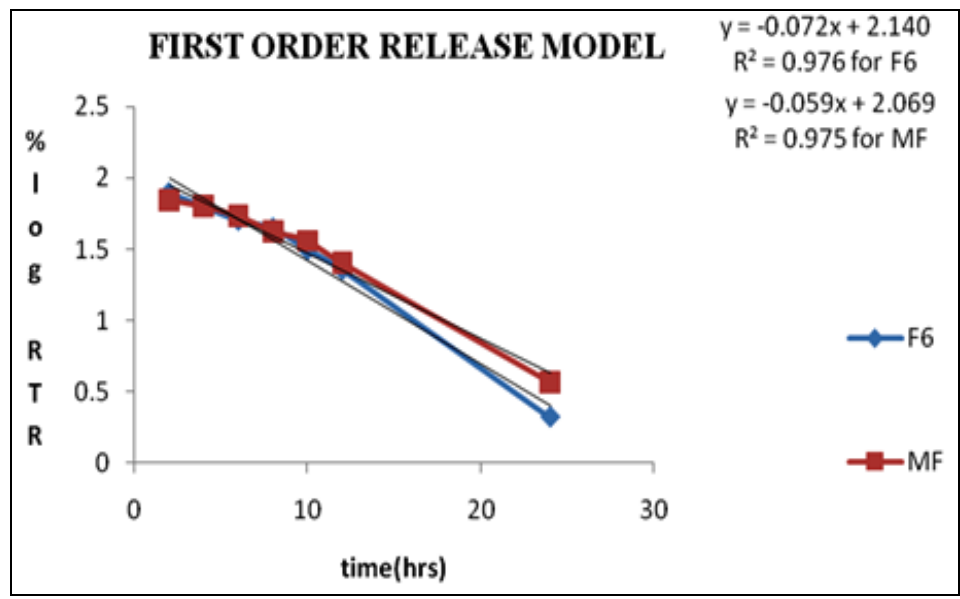

FIgURE 3: PLOT OF LOG CUMULATIVE PERCENTAGE DRUG RETAINED VS. TIME OF OPTIMIZED FORMULATION AND MARKETED FORMULATION (RTR= drug remaining to be released) 


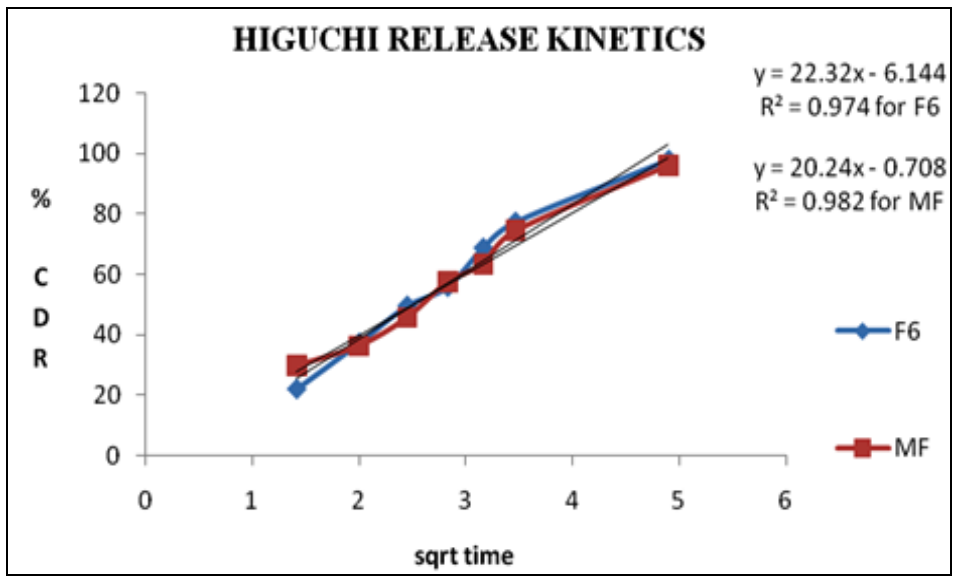

FIGURE 4: PLOT OF CUMULATIVE PERCENTAGE DRUG RELEASED VS. ROOT TIME OF OPTIMIZED FORMULATION AND MARKETED FORMULATION

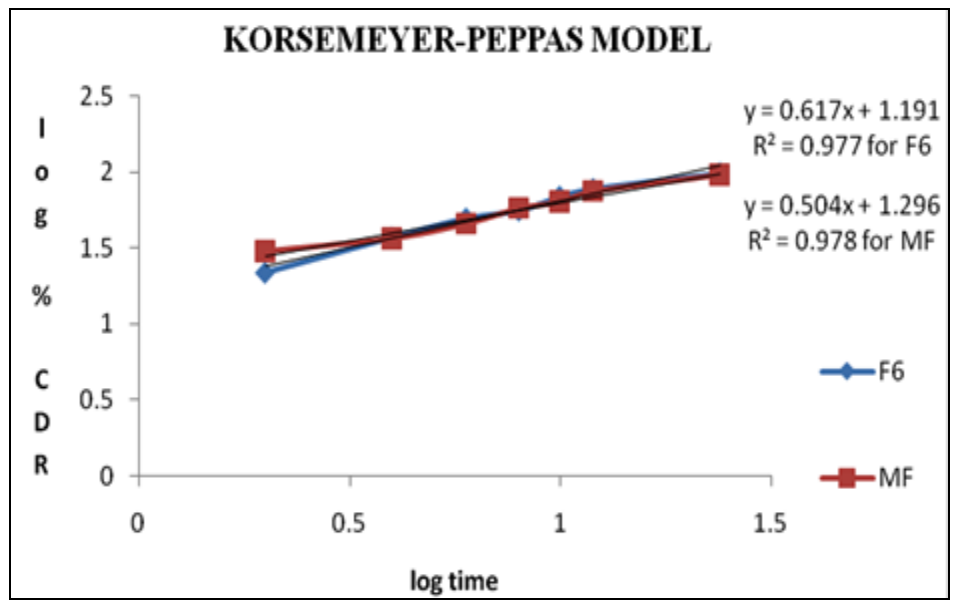

FIGURE 5: PLOT OF LOG CUMULATIVE PERCENTAGE DRUG RELEASED VS. LOG TIME OF OPTIMIZED FORMULATION AND MARKETED FORMULATION

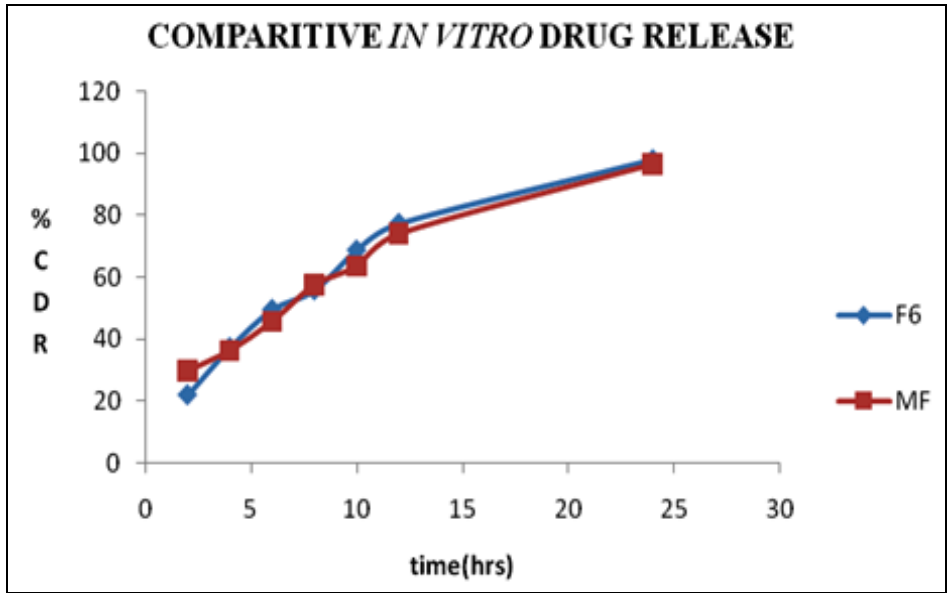

FIGURE 6: IN-VITRO DISSOLUTION PROFILE OF OPTIMIZED FORMULATION AND MARKETED FORMULATION

CONCLUSION: The effervescent based floating drug delivery was a promising approach to achieve in vitro buoyancy. The addition of gel forming polymer and gas generating agent sodium bicarbonate was essential to achieve in vitro buoyancy.
The drug release from the tablet was sufficiently sustained for $24 \mathrm{hr}$ and non fickian transport of the drug from tablet was confirmed, so drug release appears to be a complex mechanism of swelling, diffusion and erosion.

ACKNOWLEDGEMENT: The author is thankful to the almighty and Parents for their encouragement.

The author is thankful to dearest friends Vanitha and Swathi for their never ending encouragement.

The author is thankful to Sri K.V. Vishnu Raju Garu, Chairman, Dr. D. Basava Raju Garu, Director, Sri Vishnu Educational Society, for their immense interest \& support.

The author is thankful to Dr. A. Ramesh, Principal, Faculty and Administrative Staff of Vishnu Institute of Pharmaceutical Education and Research and for their kind cooperation and encouragement.

\section{REFERENCES:}

1. Hirtz J. The GIT absorption of drugs in man: a review of current concepts and methods of investigation. BrJClinPharmacol. 1985; 19:77S-83S. PubMed

2. Soppimath KS, Kulkarni RA, Rudzinski WE, Aminabhavi TM. Microspheres as floating drug delivery systems to increase gastric retention of drugs. Drug Metab Rev. 2001; 33:149Y160.

3. Deshpande AA, Rhodes CT, Shah NH, Malick AW. Controlledrelease drug delivery systems for prolonged gastric residence: an overview. Drug Dev Ind Pharm. 1996; 22:531Y540.

4. Hwang SJ, Park H, Park K. Gastric retentive drug-delivery systems.Crit Rev Ther Drug Carrier Syst. 1998; 15:243Y284.

5. Ponchel G, Irache JM. Specific and non-specific bioadhesive particulate system for oral delivery to the gastrointestinal tract. Adv Drug Del Rev. 1998; 34:191-219. PubMed DOI: 10.1016/S0169-409X(98)00040-4

6. Lenaerts VM, Gurny R. Gastrointestinal Tract- Physiological variables affecting the performance of oral sustained release dosage forms. In: Lenaerts V, Gurny R, eds. Bioadhesive Drug Delivery System. Boca Raton, FL: CRC Press; 1990.

7. Deshpande AA, Shah NH, Rhodes CT, Malick W. Development of a novel controlled-release system for gastric retention. Pharm Res. 1997; 14:815-819. PubMed DOI: 10.1023/A:1012171010492

8. Rednick $A B$, Tucker SJ, inventors. Sustained release bolus for animal husbandry. US patent 3507 952. April 22, 1970.

9. Davis SS, Stockwell AF, Taylor MJ, et al. The effect of density on the gastric emptying of single and multiple unit dosage forms. Pharm Res. 1986; 3:208-213. DOI: 10.1023/A:1016334629169

10. Urguhart J, Theeuwes $F$, inventors. Drug delivery system comprising a reservoir containing a plurality of tiny pills. US patent 4434 153. February 28, 1994.

11. Mamajek RC, Moyer ES, inventors. Drug dispensing device and method. US Patent 4207 890. June 17, 1980.

12. Fix JA, Cargill R, Engle K. Controlled gastric emptying. III. Gastric residence time of a non-disintegrating geometric shape in 
human volunteers. Pharm Res. 1993; 10:1087-1089. PubMed DOI: 10.1023/A:1018939512213

13. Kedzierewicz $F$, Thouvenot $P$, Lemut J, Etienne A, Hoffman $M$, Maincent P. Evaluation of peroral silicone dosage forms in humans by gamma-scintigraphy. J Control Release. 1999; 58:195-205. PubMed DOI: 10.1016/S0168-3659(98)00154-0

14. Groning R, Heun G. Oral dosage forms with controlled gastrointestinal transit. Drug Dev Ind Pharm. 1984; 10:527-539.
15. Groning R, Heun G. Dosage forms with controlled gastrointestinal passage-studies on the absorption of nitrofurantion. Int J Pharm. 1989; 56:111-116. DOI: 10.1016/0378-5173(89)90003-3

16. Timmermans J, Andre JM. Factors controlling the buoyancy and gastric retention capabilities of floating matrix capsules: new data for reconsidering the controversy. J Pharm Sci. 1994; 83:18-24. PubMed.

How to cite this article:

Saigeethika S, Singhvi G and Ramanjaneyulu: Formulation and Evaluation of Floating Tablets of Ofloxacin. Int J Pharm Sci Res. 3(11); $4291-4296$. 